The University of San Francisco

USF Scholarship: a digital repository @ Gleeson Library |

Geschke Center

Philosophy

College of Arts and Sciences

Winter 1-1-2006

\title{
Race and Place: Social Space in the Production of Human Kinds
}

Ronald Sundstrom

rrsundstrom@usfca.edu

Follow this and additional works at: https://repository.usfca.edu/phil

Part of the Ethics and Political Philosophy Commons, Ethnic Studies Commons, Other Philosophy Commons, and the Political Theory Commons

\section{Recommended Citation}

Sundstrom, Ronald, "Race and Place: Social Space in the Production of Human Kinds" (2006). Philosophy. 63.

https://repository.usfca.edu/phil/63

This Article is brought to you for free and open access by the College of Arts and Sciences at USF Scholarship: a digital repository @ Gleeson Library | Geschke Center. It has been accepted for inclusion in Philosophy by an authorized administrator of USF Scholarship: a digital repository @ Gleeson

Library | Geschke Center. For more information, please contact repository@usfca.edu. 
PHIL.OSOPHY \& GEOGRAPHY, VOL. 6, NO. 1, 2003

Carfax Publishing

\title{
ARTICLE
}

\section{Race and place: social space in the production of human kinds}

\author{
RONALD R SUNDSTROM \\ Department of Philosophy, University of Memphis, Memphis, TN, USA
}

\begin{abstract}
Recent discussions of human categories have suffered from an over emphasis on intention and language, and have not paid enough attention to the role of material conditions, and, specifically, of social space in the construction of human categories The relationship between human categories and social spaces is vital, especially with the categories of class, race, and gender. This paper argues that social space is not merely the consequent of the division of the world into social categories," it is constitutive of social categories. To put it more bluntly, if who we are is bound up with place, then not only do we inhabit a divided America, divided America inhabits $u s$. The second, and equally dramatic, conclusion is that attempts to transform social categories must involve the transformation of social space. When we sort people by categories, we do so spatially." with race come racialized spaces. And because our place comes to inhabit us, when we divide spatially we cannot help but to inscribe and produce categories and identities associated with our spatial divisions: with racialized spaces come race. Recognition of this dialectic is a direct challenge to the one-way considerations of social identity and social space that occurs in much urban sociology and history. Moreover, it demonstrates that there is an internal contradiction in policies-often based in urban sociology and history-i-that assume that integration can be accomplished along with the conservation of ethnic and racial identity.
\end{abstract}

"Know your place." This directive contains both a sense of social station and spatial location. These two senses of "place" reveal a relationship between human categories and social space that goes beyond the linguistic. Human categories and social space are constitutive elements of each other. Recent discussions of human categories, or what are also called human kinds, have not paid enough attention to the relationship between people and place.

In this essay, using race and racialized spaces as examples, I will argue that social space is not merely the consequent of the social; it is constitutive of the social Space is an integral aspect of the production of human categories and identities. Moreover, to transform the social, space must be transformed Neither the social nor social space will be transformed without action that attempts transformation on both planes. 


\section{Social Space}

The type of space that is taken up here as object of examination is social space. This is the space of our everyday experience and action, and it is what we, in many senses, move through in our everyday lives. Social space is the spatial component and result of social organization. It is, roughly, composed of what Ernst Cassirer called "organic," "perceptual," and "symbolic" space."

According to Cassirer, organic space is the spatial experience unique to each species, and perceptual space is the spatial experience given to the higher order species from their complex array of sensoty capabilities. Cassirer's taxonomy of space, and his speculative reflections on space are best understood through Piaget and Inhelder's empirical research on the development of spatial knowledge, and their conception of operational space as the space that humans encounter through their five senses. ${ }^{2}$ Nonetheless, Cassirer's notion of symbolic space is valuable, because it is a component, along with operational space, of human social experience As he noted, our species, through memory, myth, and the development of our understanding of abstract space, has invested our spaces with meaning. These spaces are made social, and become places

Idiosyncrasies in social and topographic experience entail idiosyncrasies in the experience of social space Nonetheless, macro social processes guatantee degrees of commonality at and across sites From Piaget and Inhelder's notion of operational space, which is universal to Homo sapiens, we get an explanation of operational commonality. The operational space of humans who are not lacking in one or more of the senses is similar, thus humans share a basic phenomenological experience of space Since, however, our species also experiences space socially, there is also room for uniqueness Uniqueness in spatial experience at social and historical sites must be true for the thesis of this paper to be true: spatial organization of groups is constitutive of the social production of groups, and there is a looping effect between spatial experience and group constitution.

Places are particular social spaces, and are infused with social use and meaning. They are spaces that have been organized according to the demands of myriad social patterns ${ }^{3}$ What results from this process is the all-inclusive and omnipresent-and often contradictory - division of the world into the familiar places of inside and outside, sacred and profane, public and private, economic and domestic, urban and rural, city and suburb, as well as places marked by race, class, gender, sexuality, and so on. ${ }^{4}$

Place involves both geographic location and social station. There is a looping effect between location and station, such that each participates in the production of the other An individual's place, therefore, is a function of that individual's geographic locations of residence and memberships in human kinds.

Both space and place are sorts of social kinds; similar to what are typically called artifactual kinds. Artifactual kinds are categories of objects of human manufacture whose reasons for existence lies wholly in their utility and purpose: furniture, art, architecture, cities, money, and other assorted tools ${ }^{5}$ As artifactual kinds social spaces are a subset of socially constructed kinds. Social categories, both human kinds and artifactual kinds, are categories of the social sciences They mark areas of human organization. It seems sensible enough to extend this idea to capture the ways humans organize geographically

Social categories are the result of social forces. Social forces are the forces that are felt by individuals and groups that emanate from the actions and demands of other individuals and groups. The social forces that produce us are various; being a mixture 
of governmental, economic, political, and cultural forces that find expression and enforcement through a multitude of institutions, as well as individual and group intentional behavior. Human kinds, or categories of people, for Michael Root, are the result of the convergence of three social forces: the force from above, the force from below, and the lateral normative forces that support the other forces. The force from above is the force of labeling, the force from below is the uptake of the so named, and the lateral forces are the normative pressures that are brought to bear on those within and without the labels to maintain the labels and the norms that go with the labels. ${ }^{6}$ For Hacking, human kinds, or what he now calls "interactive kinds," rise out of a matrix of social activity. ${ }^{7}$ Before Hacking began using the idea of the matrix, he like Root, used the notion of "vectors," or forces to explain the presence of social categories. He noted two forces: the force from above, again a labeling force, and a force from below, the force generated when the labeled take up the label ${ }^{8}$

How then are social spaces or places social kinds? Space and place are the categories of physical and human geography, as well as other human sciences. They are the result of particular forms of life and language games. They are concepts, to draw on Wittgenstein, that we understand through family resemblances. ${ }^{9}$

The notion of the family resemblances applies particularly well to the artifacts and furniture of our world. Rather than a physicalist account of these objects that confuses internal composition with use, a social account of their ontological status is more fruitful. The essence of chairs and vases will forever evade our philosophical investigations; however, such items do not seem as slippery when we fall back on the relative and contingent definitions of them given by ordinary language. Family resemblances, of course, and categories that draw on them can be vague, however they are still utilizable ${ }^{10}$ Vagueness, fuzziness, and so on characterize social categories, but that is the stuff of which the social is made.

Space and place are, as all social kinds are, the result of social and extra-social forces Social forces arise are the fibers that are twisted together to produce and distinguish individual identities, social categories, and ultimately on our "forms of life." These forces combine in such a manner as to give kinds, to varying degrees, presence and impact in our lives Due to this presence and impact, social kinds can be discovered and play a role in explanations of human behavior

\section{Ghetto}

Taking "ghetto" as an example, we can identify the three forces that make it a place in the United States. First, consider the label, the force from above. "Ghetto" is of probable Italian origin and is the short form of the Italian word "borghetto," which denoted a settlement outside the city walls. The term was used to describe old Jewish settlements. Both the short and full forms make their first appearances in the sixteenth century Italian descriptions of urban life.

In the United States the term, along with "barrio" refers to majority-minority neighborhoods, and was first used in this context in $1933^{11}$ In urban history and urban sociology, "ghetto" and "bartio," are often used to refer only to majority-minority neighborhoods that suffer from concentrated poverty and hypersegregation ${ }^{12}$ Before 1900 in the United States the ghetto did not exist, even though African Americans, Native Americans, Asian Americans and immigrants, and Latino Americans and immigrants were forced to live in racially distinct spaces ${ }^{13}$ After the end of the United States' Civil War in 1865 the pressures for ghettoization increased, and between 1900 and 
1940, with industrialization in the Northern United States and the increase of de jure Jim Crow segregation the ghetto was constructed as a concept of social space, and a physical space of hypersegregation and concentrated poverty. Today, the notion of the ghetto and barrio are an everyday part of American racial politics The ghetto and barrio are widely understood as pervasive parts of American life used to label social spaces. ${ }^{14}$

Second, consider the lateral forces, or rather, the normative forces that are used to create and maintain the category "ghetto" In the United States, 1900 marked the beginning of African American ghettoization. That year also marked the beginning of two decades of "Negrophobia," an increase of the number of lynchings in the South, and anti-black race riots, which took lives and destroyed property: in Atlanta in 1906; in East St. Louis in 1917; and in 1919 when there were around twenty-five of these riots across the nation in cities such as Chicago and Knoxville.. ${ }^{15}$ Additionally, this era saw the rise of social Darwinism, and the mass migration of African Americans to Northern industrial cities. Between 1900 and 1940, through a combination of terror (firebombing, race riots, lynching, and shooting), de facto practices, such as residential covenants, neighborhood associations, and de jure practices, such as Jim Crow codes, and red-lining in real estate and banking, the ghetto became an Ametican reality. ${ }^{16}$ Many of these practices, de facto and de jure, continued well into the 1970s. Today segregation and the ghetto persists largely through de facto and de jure practices such as suburbanization, and neighborhood zoning, that have the façade of class separation, yet result in the continuation of tacial segregation. ${ }^{17}$

Third, there is the force from below, the uptake of the label by those who are labeled. People forced to live in distinct places come to recognize, and even love, those places. As was the case with pre-war Jewish ghettos, the African American reaction to segregation has been one of struggle and resistance, but also appreciation and investment in their communities. "Ghetto" is a term that denotes a social condition that is perceived as a social ill. That there are ills associated with ghettoization is not controversial ${ }^{18}$ Yet, these places are more than ghettos, they are homes and communities. While all involved want an end to social ills and distributive injustice, they do not want an end to their neighborhoods and communities.

\section{Production of Place \& People}

When people, in the daily productions of their own lives, produce other people they do so in relation to systems of production and their products ${ }^{19}$ Aside from the sheer biological reproduction of other people, Marx and Engels argue that systems of production create kinds of people that correlate with the division of labor, and what is produced.

According to Marx and Engels, as labor is divided, as town is divided from country, laws and institutions are created, and with those normalizing forces, so are kinds of people:

The existence of the town implies, at the same time, the necessity of administration, police, taxes, etc.; in short, of the municipality, and thus of politics in general. Here first became manifest the division of the population into two great classes, which is directly based on the division of labor and on the instruments of production. The town already is in actual fact the concentration of the population, of the instruments of production, of capital, of pleasures, of 
needs, while the country demonstrates just the opposite fact, isolation and separation $^{20}$

Another corollary of systems of production, and the production of kinds of people is the production of place With the production of the town and country comes the production of industry, commerce, and agriculture, of urban labor and rural labor, and of the proletariat and bourgeoisie. As places are produced, so are people. Obviously, not only are categories of things important for Homo faber, so are categories of people ${ }^{21}$

Thus, the production of social identities can be seen in the social landscape. If we survey the social and physical landscape we will find that there is a relationship between every social identity and place. This constancy and strength of this relationship varies, and is specific to each human kind It is striking, however, that for all the central human kinds of our lives-race, ethnicity, gender, sexuality, class-there is always a separation and demarcation of places involved with the maintenance of these kinds. The relationship, for some kinds, may even be necessary. Indeed, how can there be race, ethnicity, or gender without the physical separation of the races or genders? Any necessity between the existence of kinds of people, and the existence of separate places for those kinds is due to the process of social construction of human kinds. This is a process that occurs in and through space, and it is inseparable from place.

Since the social landscape is played out in the literal landscape, we can observe the social dynamic in our private and public spaces, in our social places. Moreover, we can address this dynamic in our sociological and geographic descriptions To develop robust and socially useful human science, we ought to develop what David Harvey, in Social fustice and the City, called a sociological and geographic imagination:

the only adequate conceptual framework for understanding the city is one which encompasses and builds upon both the sociological and the geographic imaginations. We must relate social behaviour to the way in which the city assumes a certain geography, a certain spatial form We must recognize that once a particular spatial form is created it tends to institutionalize and, in some respects, to determine the future developments of social process. We need, above all, to formulate concepts which will allow us to harmonize and integrate strategies to deal with the intricacies of social process and the elements of spatial form. ${ }^{22}$

Given the mapping of social onto literal landscapes, and that the dual productions of people and place are intertwined, the metaphor of the social landscape and the socio-graphic imagination that maps that landscape are particularly useful in explorations of the function of place in the ontology of social identities.

\section{Social Space in Accounts of' Human Kinds}

The mapping of the social onto physical landscapes, in the initial and continued production of human kinds, must be taken into consideration in accounts of human kinds. In some discussions of human kinds, place, and other material conditions, disappear amid talk of "social forces" and "vectors." We get the sense, in reading these accounts, that what is meant by the social is the domain of human action-a domain that is apart from, though determinative of, material conditions

There is little mention of material conditions in Duprés work on human kinds. ${ }^{23}$ This is also the case with Root's framework Root's account of human kinds, however, 
involves "institutions," and thus allows for the inclusion of material considerations. Nonetheless, his treatment of institutions focuses on the institutional production and enforcement of norms rather than on the disciplining power that institutions, as material entities, have over our bodies and identities ${ }^{24}$

This is also apparent in Hacking's essays on human kinds that were published before The Social Construction of What? $?^{25}$ Not that material considerations are contrary to his framework; rather, Hacking overlooks them. This oversight is serious, given the power of material conditions, such as place over social formation. Hacking argued in his initial essays on human kinds that a general story cannot be told about human kinds There is a particular tale to be told about each category. All the same, just as these specific stories have in common "labels" and the pressing from "below," many stories will have a material component

In his book on social construction, Hacking addresses this oversight to some extent. In a quick discussion of the category "women refugees," he writes:

The matrix in which the idea of the woman refugee is formed is a complex of institutions, advocates, newspaper articles, lawyers, court decisions, immigration proceedings. Not to mention the material infrastructure, barriers, passports, uniforms, counters at airports, detention centers, courthouses, holiday camps for refugee children You may want to call these social because their meanings are what matter to us, but they are material, and in their sheer materiality make substantial differences to people. Conversely, ideas about women refugees make a difference to the material environment (women refugees are not violent, so there is no need for guns, but there is a great need for paper, paper, paper). Material influences that people (many of whom have no comprehension of that paper, paper, paper, paper, the different offices, the uniforms). Sheer matter, even the color of the paint on the walls, can gradually replace optimistic hope by a feeling of impersonal grinding oppression. ${ }^{26}$

Although Hacking comes to include materiality, its role remains casual as an outside constraint. I want to go farther and argue that "sheer matter" can do more than affect us; it can inhabit us.

\section{Race}

An instance of this dynamic between place and human kinds is the relationship between race and place in the United States Before I discuss this dynamic, however, I need to briefly clarify what I mean by "race." Race is a social category that has presence and impact in our world. As such it is a real human kind ${ }^{27}$ This is not to say it is a naturally occurring kind, or what others call a natural kind. Rather it is a category of human organization and experience, and is the subject of investigation by the social sciences. In contrast, naturally occurring kinds are the concern of the physical and biological sciences ${ }^{28}$

Human kinds are, along with artifactual kinds, a subset of social kinds, or, in othet words, socially constructed kinds. Social kinds are the product of social forces. Social forces combine to give social kinds a varying degree of presence and effect. The creation and alteration, moreover, of new social kinds brings with it, to use Ian Hacking's idea, the creation of new worlds ${ }^{29}$

Social kinds, as well as naturally occurring kinds, can either be real or nominal Kinds are real when they share in a relationship that is specific to their domain (i. $e_{\text {.. }}$ the 
social, biological, or physical sciences). Kinds are nominal when their members do not share a domain specific relationship ${ }^{30}$ Race is not a real biological kind because the members of what we understand as the "races" do not share a significant biological relationship: they are not united by a common morphology, or genetic sub-structure that is race specific ${ }^{31}$ However, when race is a real human kind, at some site, it is because the members of races at that site are unified by significant social relationships. To say, therefore, that some social kinds are real, rather than nominal, is not to say that they are real in the way physical or biological kinds are real. Real social kinds, or more specifically, real human kinds, are socially real, and they are so because social, political, and economic actions have made them so.

Hacking would agree that human kinds have presence and impact; however, he argues that they are "dynamically nominal" rather than real. In contrast, Root allows for the reality of social kinds. I have argued that dynamic nominalism does not provide a robust enough understanding of the presence and impact of social categories. As long as it is understood that calling a social kind "real," refers only to its ontological status in the domain of the social sciences, there is little reason in relegating human kinds to a nominal status. ${ }^{32}$

\section{Race and Place}

Race and place provides an example of the impact of social forces, and their creative, destructive, and normalizing potential. This example shows how place can come to inhabit our undetstanding of human categories, and even our identities. That we inhabit space is one thing, but how is it that space can inhabit us?

\subsection{We Inhabit space}

That human beings inhabit space socially, and thereby make places, is obvious. Despite this obviousness, humans have a tendency to forget that place has a human origin. We naturalize place, and, since social space is symbolic anyway, we make it abstract: we look at a place, say a city, and instead of seeing it as a place, a landscape, we may at various moment see it as curves, circles, grids, polygons, or as a mixture of commercial, industrial, and housing zones with transportation corridors to connect them Geometric objects and mathematical relationships were used to build the city, they can be used to represent the city digitally, by drawing, or sculpture, but they are not the city. The city is social. Forgetting this, as Lefebvre argues, those with power over social space use abstract space, erase the social with the abstract, and confuse their vista with the abstract view ${ }^{33}$

While popular vistas laud the digestible and entertaining landmarks of social identity, they have a tendency to pass over the eyesores of social identity that mark our landscape This is the case with race in America. Despite these erasures, the careful observer will see that race is literally mapped onto our American neighborhoods, towns, cities, and states. The correlation between race and place in the United States is due to centuries of de facto and de jure racial segregation and the tacialization of space ${ }^{34}$

In American Apartheid, Douglas Massey and Nancy Denton argue that "when it comes to housing and residential patterns ... race is the dominant organizing principle." Residential segregation by race has always been an important part of the history of race in the United States, with each region and group having its own particular form. US 
patterns of residential segregation by race have been persistent, slow to change, and is still a prevalent part of life in US cities today.

Racial housing and residential patterns are inexorably linked to the US system of racial hierarchy. This hierarchy, with a few exceptions, places the races on a vertical axis of status, with whites on the top, blacks on the bottom, and Asian Americans, Latin Americans, and Native Americans at points in between. The link between patterns of residential housing and racial hierarchy is strong, and is the reason why race is a dominant organizing principle. White aversions to living in neighborhoods that are majority non-white, or, more to the point, black, is not due to fear of crime or poor neighborhood quality, but rather, as St. John and Bates have demonstrated in their research on "Racial Composition and Neighborhood Evaluation," it is because race functions as a marker of status:

Data on residential segregation imply whites are averse to living in integrated neighborhoods even though survey data show prejudiced attitudes toward blacks are decreasing. This aversion could be due to whites associating crime and deterioration with black neighborhoods instead of being a reaction to racial composition or it could be due to the persistence of race as a master status in the United States with black neighborhoods perceived as having low status regardless of accompanying characteristics. The factorial survey method was used to create vignette neighborhoods in which tacial composition, ctime, deterioration, and other neighborhood characteristics are unrelated. A random sample of adults in a southwestern metropolitan area was asked to evaluate these vignettes. Controlling for neighborhood characteristics, racial composition was found to have a significant effect on neighborhood evaluation, supporting the race as master status explanation ${ }^{36}$

Race is not just expressed spatially; but is experienced and produced spatially. Race is placed, and racial places become encrusted with racial representations that become all too often materialized due to racist action and neglect. Furthermore, this race and place dynamic comes to pervade and thus shape our common sense understanding of the world by giving us, as Omi and Winant have argued, a "way of comprehending, explaining, and acting in the world." 37 This "racial common sense," which is itself a production, dovetails with institutional racism and disparity, and shapes, to use their phrase, "the very geography of American life."38 The production of racialized places, and the investment of them with social, cultural, political, and economic meaning is one of the social forces that forges racial common sense, the geography of American life, and ultimately racial categories as such.

\subsection{Place inhabits us}

Now for the not so obvious part how place comes to inhabit us. In the following subsections three ways that place comes to inhabit individual and identity are presented. Place is a component of the self-conception of individuals. Place is also a component of inter-individual conceptions. Likewise, place is a component of the way communities view themselves and how others view them. In our inhabitation of places there is a looping effect between our identification of places and our identities 


\subsubsection{Life Chances}

The racialized "geography of American life" is embodied by this nation's residential, education, commercial, work, and entertainment patterns. These racialized patterns correlate to significant differences in the availability of adequate and affordable housing, the location of public resources and goods, such as public transportation, healthcare, daycare, police and fire protection, schools, grocery stores, proximity and exposure to environmental pollution, all the way down to the availability of well-maintained sidewalks, crosswalks, bridges, and roadways.

It would be a mistake to see these matters as banalities The distributions of public goods, and access to them, have direct effects on the quality of life, life chances, and even the physiological and mental health of individuals. ${ }^{39}$ This is an old story in urban sociology, and we have heard this very refrain from Lévi-Strauss, Weber, Du Bois, and Park ${ }^{40}$ Unfortunately this old story has an everyday reality in our nation today. ${ }^{41}$

An individual's or group's raced place determines the amount of resources and social goods they will be able to access. The amount of available resources is highly correlated with quality of life and life chances. Hence, those who, because of their race, ethnicity, or class, are given little choice but to live in ghettos, bartios, under-developed rural areas, or other sites of concentrated poverty are systematically denied the benefits of society and must shoulder a disproportionate amount of its burdens. The result is that their life chances suffer.

Central to the relationship between the dynamic of race and place, and life chances is the impact of this dynamic on the physical and mental health and other psychological aspects of the individual. Stress levels and general mental health are negatively affected by exposure to racism and poverty ${ }^{42}$ This phenomenon obviously has a spatial component, and is compounded in areas of hypersegregation and concentrated poverty ${ }^{43}$

Place affects our life chances and health. Life chances and health are central to individual and community identity. Place, through these effects, inhabits us. It is, hence, one of the social forces in the production of people, groups, and the social.

\subsubsection{A Sense of Place}

According to Aitken, Basso, and Lowenthal we hang meaning on the environment in which we reside; otherwise known as our landscape ${ }^{44}$ This process is not just a matter of culture impressing itself upon place. Cultured-or racialized or gendered--places impress themselves, in a looping effect, back upon humans. ${ }^{45}$ While places serve as metonyms for all that our culture stands for and has been through, these places, marked by the humans categories they are associated with, in turn come to represent and shape those very categories.

As Golledge and Stimson observe, place is an intimate part of who we are:

... place implies a location and an integration of society, culture, and nature It generates strong psychological and emotional links between people and places These links are dependent on the range of experience that people have with places. Strong arguments have been put forward that people develop and respond to a sense of place, and it is this sense of place that identifies the felt coherence of features in a setting, as well as the feelings and emotions that the place generates. The sense of place incorporates not only the concepts of location and pattern but feelings of belonging, invasion, mystery, beauty, and fear ${ }^{46}$ 
From the frontier days of the American West, to the chocolate cities and vanilla suburbs of today, American space has been racialized. If who we are is bound up with place, then not only do we inhabit a divided America; divided America inhabits us

\subsubsection{Spatial Cognition}

The third way place comes to inhabit us is through the process of environmental cognition, spatial cognition, and the production of our mental maps. Our minds order operative space, and our cultures define symbolic space. Culturally produced symbolic spaces then become the subject of our cultural ordering

The looping effect between the social and the spatial is seen at the level of "environmental cognition," which according to Moore and Golledge is the first order of human cognition of space. Environmental cognition is "the awareness, impressions, information, images, and beliefs that people have about environments." Environmental cognition not only includes the impressions people have about their physical environments but also the "meanings, significance, and mythical-symbolic properties."

"Spatial cognition" is seen sometimes as identical to, or sometimes as a subset of, environmental cognition. Spatial cognition is our knowledge and cognitive representation, or reconstruction, of the "structure, entities and relations of space." A subset of both spatial and environmental cognition is "cognitive mapping." 48

An individual's cognitive representation of their lived environment-i.e, neighborhood, town, routes, and so on-has been called many things but is often called a mental map or cognitive map. Cognitive mapping is the way people come to know the places they inhabit Cognitive maps are the cognitive representations of the places individuals inhabit, as well as other places they frequent or pass through Cognitive maps are formed within the domains of environmental and spatial cognition, and thus inherit their social content

Mental maps are not so much representations of the physical world, as they are representations of the social-spatial world, and the social meanings of various places. Various aspects of the social world, both material and immaterial, go into the generation of these mental maps for individuals. Mental maps "include such things as the dominance of the visible form of physical elements of the city, noticeable hierarchies in structural features of the city, the simplicity of the feature, the frequency of exposure to features, the relative social and cultural values attached to various city elements, and a range of economic, social, and psychological characteristics of people themselves ${ }^{49}$

It is almost too obvious to state, given the American experience, that race plays a role in the environmental and spatial cognition, as well as in mental maps of most Americans. Ghetto, barrio, slum, bad or dangerous neighborhoods, inner city, suburb, and so on are central ideas brimming over with social-spatial meaning The dynamics of race and place shapes our everyday knowledge, understanding, and interaction with our environments and the other inhabitants of those environments. Further, although I here only hinted at it, this dynamic shapes social science geography about people and places $^{50}$

Race and place, therefore, inhabits our representations and understandings of the places in which people live, work, shop, play, and learn. Categories inhabit places, and those places come to inhabit the external and internal experiences of that group. Place is constitutive: when we sort people by categories, we do so spatially. Our system of race carries with it a spatial extension. With race come racialized spaces. And because our place comes to inhabit us, when we divide spatially we cannot help but to inscribe and 
produce categories associated with our spatial divisions. With racialized spaces come race.

\section{Conclusion}

What is gained by adding place to accounts of human kinds is a more accurate ontology Quite simply, for us to understand the farmer, bus driver, or city dweller we must consider the farm, bus, and city respectively. Likewise this holds for class, gender, and race.

Although there are classic examples of research in the human science that have realized the importance of place, most researchers who describe the relationship between social identity and place often do not emphasize the full import of this dynamic. Outside of research in geography and anthropology on spatial cognition and landscapes, the links that are made, especially in history and sociology, tend to emphasize causal one-way trajectories from social identities to place to behavior. Most work on race and gender and their relationship to space misses this dynamic. Those social scientists, and the occasional philosophers, who seek to hold some particular identity constant but change its material conditions, do not understand the constitution of the categories they are working with. Thus, adding place to our accounts provides another tool for critiques of social scientific methodology.

Adding materiality gives us something a little heavier than just performance and intentions. Since the language of social construction is often turned to for political purposes, or as Hacking puts it, when we want to question the inevitability of some social formation or activity, this addition alerts us to the difficulty of the subject we have put our hands upon.

Once place and material conditions are added into accounts of human kinds, it becomes possible to recognize that categories themselves are changed when the material conditions that surround or are part of a category are changed. Understanding the full import of this dynamic will augment our political and social efforts regarding social identities. If we want to arrest the production of questionable human kinds, then we must address the production of spaces that create, maintain, and represent them. Remove the iron bars, concrete slabs, and rails that demarcate and police categories, and the category itself will change. If we remove the classed, gendered, and racialized places, we may find ourselves with very different kinds of people

\section{Notes}

1 Ernst Cassirer, An Essay on Man (New Haven: Yale University Press, 1944), 42-43. Cassirer's discussion of space makes use of a flawed and ethnocentric notion of the primitive and contemporary "primitive" men.

2. Jean Piaget and Barbel Inhelder, The Child's Conception of Space (New York: Norton, 1967)

3. R. G. Golledge and R. J. Stimson, Spatial Behavior (New York: Guilford, 1997), 393.

4. Henri Lefebvre, The Production of Space (Trans. Donald Nicholson-Smith Oxford: Blackwell, [1974] 1991)

5. For more on artifactuals kinds see David M. Armstrong, Universals: An Opinionated Introduction (Boulder: Westview Press, 1989). The view of artifactual kinds that I am implicitly criticizing is Saul Kripke's, as given in his Naming and Necessity (Oxford: Basil Blackwell, 1980)

6. Michael Root, "How We Divide the World," Philosophy of Science, 67 (2000): 628-39.

7. Ian Hacking, The Social Construction of What? (Cambridge: Harvard University Press, 1999)

8. Ian Hacking, "Making Up People," in Reconstructing Individualism, eds T. Heller, M Sosna and D Wellberry (Stanford: Stanford University Press, 1986), 222-36 
9. Ludwig Wittgenstein, Philosophical Investigations (Trans GE M. Anscombe Englewood Cliffs: PrenticeHall, 1953), 67.

10. Wittgenstein, Philosophical Investigations, 69

11. Douglas Massey and Nancy A Denton, American Apartheid (Cambridge: Harvard University Press, 1993), 32

12 Paul Jargowsky, Poverty and Place (New York: Russell Sage Foundation, 1996).

13 Reynolds Farley and William H. Frey, "Changes In the Segregation Of Whites From Blacks During The 1980s," American Sociological Review, 59 (1994): 23-45; and Massey and Denton, American Apartheid. For a broader history of segregation see C Van Woodward, The Strange Career of fim Crow (New York: Oxford University Press Woodward [1955] 1974)

14. Reynolds Farley, The New American Reality (New York: Russell Sage Foundation, 1996); Jargowsky, Poverty and Place; and Massey and Denton, American Aparthied

15. Woodward, The Strange Career of fim Crow.

16. George M. Fredrickson, White Supremacy (New York: Oxford University Press, 1981); Farley, The New American Reality; and Massey and Denton, American Apartheid.

17 Michael Omi and Howard Winant, Racial Formation in the United States (New York: Routledge, 1994); and Massey and Denton, American Apartheid.

18 D. Massey, A. Gross, and M. L. Eggers, "Segregation, the Concentration of Poverty, and the Life Chances of Individuals," Social Science Research, 20 (1991): 397-420

19 See Karl Marx and Frederick Engels, The German Ideology (Trans. Lawrence and Wishurt New York: International Publishers, [1846] 1970), 49

20. Marx and Engels, The German Ideology, 69

21. See Hacking, The Social Construction of What?, for his comments about Homo faber and natural kinds

22 David Harvey, Social fustice and the City (Baltimore: John Hopkins University Press, 1973), 27.

23 John Dupré, "Human Kinds," in The Latest on the Best, ed John Dupré (Cambridge: MIT, 1987), $327-48$.

24 Root, "How We Divide The World."

25 Hacking, "Making Up People"; "A Tradition Of Natural Kinds," Philosophical Studies, 61 (1991): 109-26; "World-Making by Kind-Making," in How Classification Works, eds M Douglas and D. Hull (Edinburgh: Edinburgh University Press, 1992), 108-238

26. Hacking, The Social Construction of What?, 10-11.

27. Ronald Sundstrom, "Being \& Being Mixed Race," Social Theory and Practice, 27 (2001): 1-23; "Race as a Human Kind," Philosophy and Social Criticism, 28, no 1 (2002): 93-1 17; "Racial Nominalism," foumal of Social Philosophy, 33, no. 2 (2002): 193-210. My discussions of race are concerned with its ontological status as a social category. My conception of race also contains, however, what Appiah calls racial identity "Race, Culture, Identity," in Color Conscious, eds A. Appiah and A. Gutman (Princeton: Princeton University Press, 1996), 30-105. When I use the term "race" or a term for a particular race, such as "whites," I refer to a social category that we use to sort people, as well as a racial identity.

28. I am not asserting that this division is absolute. Researchers in the biomedical sciences, for example, deal with the intersection of social categories and medicine (i e race, sexuality, class, and etc). That this occurs does not mean that these categories are biological; rather, it shows how the social can impinge on the biological For a discussion of why race is not a valid biological category see $I$. Cavalli-Sforza, P. Menozzi, and A. Piazza, The History and Geography of Human Genes (Princeton: Princeton University Press, 1994).

29 Hacking, "World-Making by Kind-Making."

30 Root, "How We Divide The World."

31. Cavalli-Sforza, The History and Geography of Human Genes

32 Sundstrom, "Racial Nominalism"

33 Lefebvre, The Production of Space, 50-51

34 Farley, The New American Reality; Massey and Denton, American Apartheid; and Woodward, The Strange Career of Fim Crow

35. Massey and Denton, American Apartheid, 114.

36. Craig St. John and Nancy A Bates, "Racial Composition and Neighborhood Evaluation," Social Science Research, 19 (1990): 47

37. Omi and Winant, Racial Formation in the Unted States, 60.

38. Omi and Winant, Racial Formation in the United States, vii.

39. Katherine Boo's "After Welfare," The New Yorker (9 April, 2001), 93-107, gives a current and compelling story about poverty, life chances, health, and place. 
40 Claude Lévi-Strauss, Structural Anthropology, Trans. C. Jacobson, and B. G. Schoepf (New York: Basic Books, 1963); Max Weber, The City, Trans. D Martindale and G Neuwirth (Glencoe: The Free Press, 1958); W. E. B Du Bois, The Philadelphia Negro (Philadelphia: U of Pennsylvania, [1899] 1996); and R E. Park, E. W.. Burgess, and Roderick D McKenzie, The City (Chicago: University of Chicago Press, 1967).

41 Council of Economic Advisers, Changing America (Washington DC: Council of Economic Advisers for the President's Initiative on Race, 1998) The Council of Economic Adivsors' report suffers from its desire from optimism. It is valuable, however, and I cite it because it shows that the recognition of the relationships between race, place, and distributive justice is not just occurring within the Academy. For the unabashed story see Massey and Denton's American Apartheid and Jargowsky's Poverty and Place. For a devoted discussion of neighborhood effects on well-being see I. G Ellen and M. A Turner, "Does Neighborhood Matter?" Housing Policy Debate, 8, no 4 (1997): 833-66

42. D. R. Williams, Y Yan, J. S. Jackson, and N. Anderson, "Racial differences in physical and mental health: Socioeconomic status, stress, and discrimination," fournal of Health Psychology, 2 (1997): 335-51

43 Ellen and Turner, "Does Neighborhood Matter?"; and Christopher Smith, "Neighborhood Effects on Mental Health," in Geography and the Urban Environment, Vol 3, eds D T Herbert and R J Johnston (New York: John Wiley and Sons Smith, 1980), 363-415.

44. S. C Aitken, S I Cutter, K. E. Foote, and J. I. Sell, "Environmental Perception and Behavioral Geography," in Geography in America, eds G. L Gaile and C. J. Wilmott (Columbus: Merill, 1994), 218-38; Keith H. Basso, Wisdom Sits in Places (Albuquerque: University of New Mexico Press, 1996); and D. Lowenthal, "Past Time, Present Place," The Geographical Review, 65 (1975): 1-36

45. Golledge and Stimson, Spatial Behavior, 392.

46. Golledge and Stimson, Spatial Behavior, 393

47. G. T. Moore and R. G. Golledge, "Environmental Knowing," in Environmental Knowing, eds G. T Moore, and R. G. Golledge (Strudsburg: Dowden, Hutchinson \& Ross Moore and Golledge, 1976), xii 48. Golledge and Stimson, Spatial Behavior, 224

49 L J. King and R. G. Golledge, Cities, Space, and Behavior (Englewood Cliffs: Prentice-Hall, 1978), 252

50. Donna Harraway, "T eddy Bear Patriarchy," in Cultures of United States Imperialism, eds A Kaplan and D. E Pease (Durham: Duke University Press, 1993), 237-91

\section{Note on Contributor}

Ronald Sundstrom is an assistant professor of philosophy at the University of Memphis. Professor Sundstrom is a recipient of a Ford Fellowship He teaches and publishes in the areas of political and social philosophy, philosophy of social science, African American philosophy, and the philosophy of race 